\title{
Craufurd, storyteller
}

Tiago Mata, University College London, t.mata@ucl.ac.uk

Harro Maas, University of Lausanne, harro.maas@unil.ch

Historians, one would assume, are practiced storytellers. Not all historians are storytellers of the same caliber or are fortunate to have lived lives worth recounting. As regular visitors to Duke University and once fellows of its Center for the History of Political Economy, the authors of this essay knew Craufurd Goodwin as an accomplished storyteller. We sat together over innumerable lunches at the refrectory of the Divinity School and at Craufurd's office before and after seminars enthralled by his repertoire of tales of people, institutions and events. Craufurd scripted these stories as dialogues punctuated with frequents "then/so he said" and as he told them he would lean in and modulate his voice, not to convey some caricature of the dramatis personae but to bring emphasis, pace, and hit a punch line before surrendering to laughter. The little stories were bite sized, well crafted and rehearsed, and they adorned the point he wanted to make. Sometimes there was no point, but merely the thrill of the story. We review these stories because we believe them to be integral to Craufurd's approach to life as a scholar. We believe that the themes of Craufurd's storytelling speak to his role and demeanor within the community of history of economics.

In 2009, as Craufurd was stepping down from a 40-year tenure as editor of this journal, we interviewed him, video camera and audio recorder at the ready. We thought we knew Craufurd well and that by spending a few weeks with his bibliography we would discover much of the rest. With a long question sheet we set out to elicit a record of his life and career in his own voice. The resulting nearly six hours of conversation, over two days, are the primary source material for this contribution. We quote from the interview transcript but we direct our attention not to particular answers of phrases but to three complementary topics that link his 
stories together. ${ }^{1}$ We begin by reviewing how Craufurd explained his decision to become an historian of economics. The second section looks across Craufurd's descriptions of his unique set of research interests and what drew him to them. The third outlines Craufurd's views on the discipline of the history of economics and its promised usefulness. The three facets demonstrate Craufurd's attitude towards telling the story of his lived experience as a third person narrator with both investment and detachment. We believe Craufurd's storytelling is analogous to his attitude towards the community of historians of economics, with a great capacity for enthusiasm, advocacy and service but also agnostic and withdrawn from the impulse to direct or claim ownership.

\section{"It was a done deal"}

One of Craufurd Goodwin's most significant essays, among his most widely read and cited, is an account of the sources of financial support for economic research from the 1930s to the 1960s, at the time of a major reorientation of the economics discipline (Goodwin 1998). Goodwin described these "patrons" as actors in the process of selecting and elevating ideas, while arguing that intellectual innovation may be less likely to be shaped by paymasters. Craufurd's account of becoming an historian of economics was a story of the encouragement of patrons, of the steering of a young man into a profession, albeit with freedom to make of it what he wished. He told us of his decision to study at Duke, that

I didn't know what graduate school was and couldn't care less. He [Steve Hymer, his closest friend in McGill] went to several American Universities for summer school so

\footnotetext{
1 The transcript of the interview(s) was produced in the Winter of 2017-18 and therefore was not reviewed by Craufurd. Craufurd did see a video edited version of the interview in 2009 that has since been posted on Tiago Mata's YouTube channel, see https://www.youtube.com/watch?v=uLjmq3BFWV4 and https://www.youtube.com/watch?v=xg3Renh9DHk.
} 
when it came time for applications he got very good offers... we talked about it and I decided to apply and he said, they will pay lots of money. So basically I just took the place with the most money, which was Duke. I got fifty cents from Chicago, a dollar and a half from Harvard, but Duke thousands of dollars! [laughs]

At another point of the interview, Craufurd continued that

I ended up coming down here, I thought for just a year, and then stayed on and did history of thought because of Spengler's intervention. What he would do at the end of each year was pick the students he wanted to work with him and he had money and he made sure they stayed.... Spengler would often group people around some theme he was working on. In my case it was the relationship between national culture and the evolution of economic thought and vice versa, the interaction. ... And he said, if you do a thesis that I suggest and you do all the courses I suggest we will get you out of here in two and a half years. It was a done deal. And I went on to go into the economics world. But I never would have done it without him. And he had money to do history of economics; he said, I want you to do this study of Canada, ...

That study became Craufurd's doctoral thesis and first book (Goodwin 1961).

Craufurd would have us believe that his career had been a series of decisions of the moment devoid of grand design. Opportunities came to him but he also came to them. He had never intended to a career in economics, but was on his second degree in economics when he met Spengler. Although it is plausible that at the time he did his Masters he imagined a future as a lawyer in the tradition of his family, it is also true that he was already in the "economics world." Duke University paid for his education and then Spengler's patronage and persuasiveness steered him to history. Many of his career landmarks are told in the same way. It was the Ford Foundation that sought him with an offer he could not refuse, the same unsolicited and irresistible allure drew him to lead major projects for the Brookings Institution (Goodwin 1975; 1981) and for the International Institute of Education (Goodwin and Nacht 1983; 1988). 
At times the story turns pivot not upon opportunities but upon tragedies. Craufurd told us of how he became editor of History of Political Economy because his co-founder, Bob Smith, died prematurely of campus strife, tobacco and a heart attack. It took prodding before Craufurd admitted to a more active role in creating the journal. He told us how he persuaded Duke University Press, that,

Well, you see, I was sort of deputy Provost, which is the guy who runs the place. And so I was in charge of the University Press. I was in charge of their budget. So I was pretty sure [laughing] I went to them and said wouldn't you want to start a new journal? Uhuuu...they said.... we are pretty sure it's not gonna work but if you say you want to do it, we'll do it.

The Press, however, was not asked to pay for the journal. National Science Foundation and Rockefeller grants paid for it in its first five years, promotional persistence by Craufurd's letter writing got it the requisite subscription base and convinced the Press to keep it. It was all Craufurd's doing, is the picture that slowly takes shape as we talked around the puzzle pieces of the journal's origins.

What came across from the stories told and not told was neither humbleness nor embarrassment with success but an unwillingness to declare his own record through self-praise. We got glimpses of the same attitude when we discussed his role as Vice-Provost at Duke University facing the trustees' opposition to the arrival of black students on campus, or in managing the student revolts of the late 1960s (the only time ever that he could not get himself to fall asleep at night). When our conversation veered towards his time at the Ford Foundation, it was almost all about the formidable men of the Foundation, and the wealth of funds and discretion program officers like himself were given. 
The unifying thread of Craufurd's account of his career was his encounters with patrons, Spengler in the economics faculty, Duke Provost Taylor Cole, Ford Foundation President McGeorge Bundy. At each juncture of Craufurd's career seemed to stand one such man with a promise of employment. What was muted by this storytelling was Craufurd's expression of his passions or of a sense of calling. It is only by zooming in, and adding up, that we began to appreciate Craufurd's resolve and control over his own fate. Craufurd wanted us to believe that his identity as historian of economics, and much else, was accidental and that the expression of his intent was what he made of those posts and resources, how he leveraged them as advocate and himself patron of so many historians of economics.

\section{"It was fun"}

One imagines that the author of "Cyberpunk and Chicago" (Rogers, Goodwin 2002) who, alone, wrote on the economics of Roger Fry, Virginia Wolff, Walter Lippmann, and many more women and men of letters far from the canon of economics, might appreciate our attention to stories and what they convey. And yet, Craufurd never constructed a defense of how his literary and artistic subjects might offer privileged standpoints deserving of the attention of historians. When asked to defend fiction as observation, Goodwin (2012) instead wrote an essay that cast the writings of Frank Norris and E. M. Forster against the context of their times but without an analytical lesson. Craufurd's historical judgment and sensibilities were not framed by philosophical preoccupations or historiographical controversies.

One has to pick up a long forgotten forty-year-old text to observe Goodwin (1972) prescribe a model for the study of the history of economics. Written only a few years after the first issue of History of Political Economy, this American Economic Review article pictured a diamond scheme (p. 413) with vertices on four activities: formulation of economic theory, (professional) enunciation of policy implications, (non-professional) opinion of policy, and economic activity itself, with effects or impacts radiating from each component to all others. The model clarified a 
lexicon of relationships that would aid the study of the evolution of theory in its social context. In the same piece Goodwin decried the "concentration on narrative" to the detriment of "scientific technique," charging that historians were "frightened by the complexities of using social science tools on data." These were views that Goodwin did not commit to in the long term, and besides calling for a (Lakatosian) theory of the history of economics later in the decade (Goodwin 1980) what is surprising is not the scientism of these programmatic essays, but that someone of his eminence wrote so few of them. Craufurd's historiography, much like his career, was not subordinate to a grand design, it emerged serendipitously.

When we pressed Craufurd for explanations of his choice of subjects, one term appeared over and over in the answers and the accompanying stories: it was "fun." Speaking of reading Virginia Wolff as a policy analyst, and adversities in getting such a notion to print, Craufurd assured us "it was fun to do. I enjoyed doing it." And on his study on Roger Fry, he told us that “[Fry] wrote seventeen hundred articles I was able to track down. And they ran every possible subject and so, it was just fun to work on him. I get bored..." What was behind this and other fun? What made some topics fun and others boring?

While reviewing his fascination for Fry, Craufurd explained that "to begin with, he was an eclectic and I like eclecticism. And he believed he could understand virtually anything in about 20 minutes. ..., he was interested in physics. He was a double first in science at Cambridge, and that is when he abandoned science and went into painting. But ... he is now viewed as one of the pioneer architects in Britain." One is tempted to describe Craufurd projecting his own omnivorous interests to the figure of Fry, but that would be too easy of an explanation. Craufurd was drawn to the economics of non-economists, his choice authors were unpredictable and unruly and it was a riveting exercise to make them out as economists. It was like yielding a philosopher's stone of the history of economics, from literary lead to economic gold. Alongside this intellectual pleasure of reading widely about wide minds, Craufurd's fun 
was to be out in the world. Working with Michael Nacht over several summers in the employment of the International Institute of Education, he decided to go "to the actual institutions of higher education in the country and find what they were doing about foreign students, and that turned out to be tremendous amount of fun. We had a really wonderful time, we visited 50 colleges and Universities, " in another project that "was great fun was on the impact of an American education on a foreign student. So we went all around the world, interview people who had done degrees in this country." Fun was therefore not only to be had with history of economics. Craufurd's time at the Ford Foundation was "just lots of fun! You never knew what was going to happen,..." Fun was not only research. Craufurd told us that "I have taught many different subjects, which is sort of fun. I even taught the graduate labor course here, in the sixties" and that the teaching was a special thrill when he took the "TAs with me and they are great fun to have in class. ..., we would just have a discussion in front of the students."

Scholarship was fun when it called for reading widely, travelling the country and the world, commanding a new subject to teach it, and delivering it polemically. Editing History of Political Economy and the Cambridge University Press series did not prompt similar assessments. At the moment of his retirement, Craufurd spoke of his time as editor as being regularly target of "vituperation" by aggrieved authors and disappointed with lack of novelty in the submissions. He declared that he deferred most decisions to referees and to the advice of his board, to shelter himself from these weekly scandals that otherwise might have consumed all his time and energy. He admitted that the journal might have been better had he acted differently and been more directive. Whatever enjoyment and satisfaction Craufurd took from editing the journal, which he must have to have done it so judiciously and for so long, it was not "fun."

Craufurd 's enthusiasm revived itself regularly as he engrossed himself in a new project - a book, a conference, .... When we interviewed him in 2009, he was energized that the Center at Duke 
might train a new generation of historians of economics in sufficient numbers to revive the discipline. In the 1970s he was eloquent on the prospect that historians might distill the record of policy knowledge for the enlightenment of economists. But his enthusiasms could also be fleeting and extinguish themselves from memory. He showed no strong attachment, only a faint recollection, of those few manifestos he put to print in the 1970s.

The theme of "fun" may suggest egotism, but Craufurd dispelled that prejudice with a strong sense of civic duty seen by his valuing of scholarship that promised impact, and in particular was consequential for policy change. About his first summer project with Michael Nacht, Absence of Decision, on Universities policies towards foreign students, he emphasized to us that it had a really huge impact, I mean, we were on the front pages of major newspapers, all around the world, because we were very critical. Basically we said, this is a burgeoning subject and nobody is thinking about it.

But the work that he valued most and felt was least recognized and understood were the two research projects he led for the Brookings Institution on inflation and energy policies. The first Exhortations and Controls was a collection of studies on inflation policy of each Presidency since the second World War. It was

on the frontpage of the major newspapers and then it became a sort of reference work for, particularly, journalists. I used to occasionally run into that, who wanted to get an authoritative view of what happened in the Kennedy Administration or the Truman administration or something. And that was a whole new view of how the history of economics could be used... I mean we were no longer remote, doing our little thing in our little conference.

And if the media attention was not sufficient evidence, there was a really, a fantastic concluding conference at the Kennedy Library in Boston and they brought together. ... everybody that we had referred that was still alive and willing to come. So we had heads of corporations, probably twenty-five cabinet members, all of the 
living members of the Council of Economic Advisers. It was amazing. We gave papers and interacted with these people. And then we had a big party at John Kenneth Galbraith's home. That was his book launch for us. And, this, I mean it was opening the field to a much larger community. And, Joe [Pechman] was so happy with the result that we decided to proceed with more, and we did one then on energy policy which had the same sort of characteristics and it was equally successful, I think. And we were going to do one in agriculture, and then Kermit [Gordon] died, and Joe retired, and the whole thing... you know.

"You know" meant that what was opening closed. History done in an open field, appealing to a broad and powerful community was Craufurd's highlight of his career.

The key to understand Craufurd's historical predilections was to consider where the topic would take him, to whose company (authors to read, people to interview, scholars to collaborate with, high culture and high politics), to what surprises, to what effect. The joy was in the process and he did not linger, he invariably executed on deadline, ensuring that he was free to start on another project.

\section{"Big people"}

When we approached Craufurd in 2009 with a mind of reviewing his record as editor of History of Political Economy, we had been encouraged to read his recently published entry to the New Palgrave Dictionary of Economics where he had set out a history of the history of economic thought community (Goodwin 2008). The stand out claim of that entry was that the history of economics "peaked" in the middle decades of the twentieth century, from World War I until the 1960s, when some of the most gifted and respected members of the economics discipline endorsed the field and used it as a "heuristic device" - J. A. Schumpeter, Gottfried Haberler, Fritz Machlup, Lionel Robbins, Frank Knight, George Stigler, Jacob Viner, Wesley Mitchell, John R. 
Commons, John Kenneth Galbraith, Eric Roll, Martin Bronfenbrenner, Maurice Dobb, Piero Sraffa, G. L. S. Shackle, and even John Maynard Keynes himself.

Sociological common sense (and Pierre Bourdieu) tells us that for there to be a discipline of the history of economics there must be self-identification, dedicated journals and learned societies devoted to its study. Craufurd's career that included creating and nurturing many of these instruments and institutions that have now served us for nearly 50 years, reminded us that there was so much more before the founding of History of Political Economy in 1969. Craufurd claimed company with some of the distinguished men of economics: Spengler was his teacher and a dominant presence; Robbins was hostile to him personally for starting a journal; Stigler was generous to him and to the journal, but also a toxic presence capable of vicious attacks that turned people away.

In Goodwin's 2000s dictionary entry, the "golden age" of the history of economics ended around the time he came of age as a scholar..$^{2}$ The history of economics of the "golden age" was a device in the service of theory development, that role was no longer viable. It was certainly not how Goodwin wrote history. Rather, his work endorsed the history of economics as a tool of audit. It was this way that Craufurd secured Ford Foundation funding for the history of economics, writing a memorandum to McGeorge Bundy arguing

that the social sciences have evolved, more technical and sophisticated but out of touch with the real world and with policy issues, and we should be thinking about this because we are putting 30 million a year into the social sciences. So Bundy writes, Holy Christ, I didn't know that! He was very impetuous, he called a meeting of all the senior staff, like

\footnotetext{
${ }^{2}$ As Roy Weintraub (2005) has noted, it is a well-known effect of the cognitive psychology of memory that the remembrance is not uniform across one's lifetime. One can speculate whether Craufurd's periodization is to some extent a consequence of the "bump" of autobiographical recall, making the time of his early adulthood more poignant, more golden.
} 
fifty people in the Foundation, for the next morning! At 9 o'clock I had to go and present this, .... we initiated a discussion that went on for some months in the Foundation about whether we should continue to support the social sciences since they were evolving in the way they were and so. I think that gave me a case for supporting the history of thought for the next few years, to understand this phenomenon better.

The Bundy memo was confrontational, it threatened the funding of the social sciences for their lack of socio-political awareness, Craufurd's later advice was that this audit should remain "a very subtle role and I don't know how you get the discipline to pay attention to it. And it particularly doesn't pay attention to it if you become hortatory and angry." The historian as analyst would aid economists to become more "self-aware" but could not see economists asking for this kind of help.

Craufurd was in the company of the grandees of the economics profession as a student and as a junior faculty, but his professional life was punctuated by the unabating loss of prestige and place of the history of economics in the economics profession. In our interview he seemed to explain this transformation as a loss of stature of the historians. Craufurd remembered Spengler as "big people," "big in the national scene," a "dominant person in this department, from whenever he came, sort of 1930, till the time he died, well after the time he retired. He was an extremely tough, strong willed guy, and if you got in his way he would eat your head off." After much insistence from us asking why the promise of the 1970s - of a new journal, of a society, of a crisis of economics calling for self-examination, of the Brookings volumes - had not been realized, Craufurd concluded that "if people of their mettle and standing had been around in the 1970s maybe they could have done something." The key to failure, or success, was not a redesigned theory for the discipline, better institutions, or the courting of audiences with appropriate topics and language, it was men of stature and resolve, and Craufurd speculated that a "great connector" might still emerge to link the history of economics with the mainstream of the discipline. 
Although we cannot be sure, because we never asked, it seems to us that Craufurd was not desirous of a return to a "golden age." It was to him both too remote and too difficult but also uninteresting. To his sensibility the future of historians of economics was to become analysts for self-knowledge or auditors of policy knowledge, forever distinct from economists but with a crucial complementary role to play.

\section{Witnessing history}

Craufurd was the grandson of a premier of Prince Edward Island, James D. Stewart, premier from 1923-1927 and 1931-1933 - which he assured us did not mean much, it was a small province and everyone was related. He was the son of a banker and of a civil rights lawyer and activist. He must have lived an early contradictory life: his mother a daring opponent of the English establishment in Quebec, his father twelve years her senior and its embodiment.. He was prompt to tell us about his mother, Roma Stewart, less about his father, George Goodwin. He told us that she

was trained as a lawyer and the first person who was called to the bar at the Canadian Maritimes, the first woman. And, she went to Dalhousie Law School uh... as a special student, they wouldn't admit her because she was a woman. She was allowed - she was always very bitter about this - she was allowed to go to classes, and then at the end of the legal program she got the gold medal ....but they wouldn't give it to her because she was a woman. ... when she moved to Montreal she was part of a little group who used to sue people who did bad civil rights infractions. And they were very good lawyers so they usually won their cases. The most famous one was they sued the premier of Quebec, who disliked Witnesses of Jehovah so he persecuted them in various ways. They sued him as an individual for a mistreatment of a restaurant owner from whom he had taken the liquor license, essentially destroying his business. And they bankrupted the Premier, 
so this was a major case. I can still remember the party in our house when they had this case. $^{3}$

These simple personal details are significant at the end of our essay as a reminder that this was not a study of Craufurd's character or psychology. For that the reader should seek a copy of Roma Stewart Goodwin's memoir, "Heart and Home," that is rich in detail about the family's life, including Craufurd's and brother Harvey's childish exploits. ${ }^{4}$ We reproduce this family storytelling because we read in it Craufurd's detachment from the story. As he lists his mother's achievements and her struggle, he refrains from adding his emotions into the tale, other than remembering the party.

Examining Craufurd's storytelling we were impressed by how it is both personal and detached. Oral historians often find communities held together by individuals who, by virtue of seniority or talent, become keepers and carers of an oral tradition and of collective memory (Perks, Thompson 1998). Craufurd would be a good candidate for that role, but his storytelling is of a different sort than the lore of oral traditions since what Craufurd shared were his own lived

${ }^{3}$ The case was Roncarelli vs Duplessis heard by the Canadian Supreme Court in 1959, although the memorable house party would have been much earlier. Roma Stewart Goodwin was not the first woman admitted to the bar at the Canadian Maritimes, that honor befalls Frances Lillian Fish (Cahill 2011). Craufurd did not mention the intriguing but perhaps too personal fact that after his father's death, his mother remarried to a distinguished Duke Professor, William Maxwell Blackburn, and lived her final years near her son. Her papers are housed at Duke University Library.

${ }^{4}$ It seems to us inevitable that one day the legacy and brilliance of Craufurd Goodwin must be subject to careful study. Scholars will have a rich set of materials to work from, Roma Stewart Goodwin's memoir, the trove of documents Craufurd kept in his personal files now deposited at the Economists Papers Project, material at the Ford Foundation and at Duke University Archives where he was vice-provost, dean, and much else. 
experiences not stories passed on. And these personal stories were told as a witness; just like a third person narrator in a novel asserting the veracity of the events with a cold and detailed gaze. The third person narrator's most fascinating trait is its power of omniscience. Craufurd moved between omniscience and participation. He oversaw the history of economics from the editorship of the field's most prestigious journal, or international economics from the role of program officer at the Ford foundation. He was also eager to leave his office at the top of the University Library and travel the world to interview, to study archives, to discuss with policy makers and journalists. Craufurd's stories were social documents of the travels that an extraordinary historian of economics had accomplished. Experiences frozen into anecdotes, they speak to us of a life that looks like a "golden age." 


\section{References}

Blackburn, Roma Goodwin. 2008. “Heart and Home: A Memoir” Legal Studies Forum. 32(2): 685836.

Cahill, Barry. 2011. “Everybody Called Her Frank”: The Odyssey of an Early Woman Lawyer in New Brunswick', Journal of New Brunswick Studies / Revue D'études Sur Le Nouveau-Brunswick, 2 (2011) <https://journals.lib.unb.ca/index.php/JNBS/article/view/18735/20494\#no6> [accessed 28 March 2018]

Goodwin, Craufurd D., 1961. Canadian economic thought: the political economy of a developing nation, 1814-1914. Duke University Press.

Goodwin, Craufurd D. 1972. 'Economic Theory and Society: A Plea for Process Analysis', The American Economic Review, 62 (1/2): 409-15.

Goodwin, Craufurd D. (ed.) 1975. Exhortation and Controls : The Search for a Wage-Price Policy, 1945-1971. Washington, D.C.: Brookings Institution.

Goodwin, Craufurd D. 1980. 'Toward a Theory of the History of Economics', History of Political Economy, 12: 610-19.

Goodwin, Craufurd D. (ed.) 1981. Energy Policy in Perspective: Today's Problems, Yesterday's Solutions. Washington, DC: The Brookings Institution.

Goodwin, Craufurd D. 1998. 'The Patrons of Economics in a Time of Transformation', History of Political Economy, 30 (suppl.): 53-81. 
Goodwin, Craufurd D. 2008. "History of Economic Thought." In Durlauf, Steven N. and Blume, Lawrence E., eds., The New Palgrave Dictionary of Economics. Second edition (online). London: Palgrave Macmillan. <https://doi.org/10.1057/978-1-349-95121-5_2624-1>.

Goodwin, Craufurd D. 2012. 'Observation through Fiction: Frank Norris and E. M. Forster', History of Political Economy, 44 (2012), 206-25.

Goodwin, Craufurd D. and Nacht, Michael, 1983. Absence of Decision. Foreign Students in American Colleges and Universities. A Report on Policy Formation and the Lack Thereof. IIE Research Report Number One.

Goodwin, Craufurd D. and Michael. Nacht. 1988. Abroad and beyond: Patterns in American Overseas Education. Cambridge University Press.

Perks, Robert., and Alistair. Thomson. 1998. The Oral History Reader. London: Routledge.

Rogers, Alex, and Craufurd D. Goodwin. 2002. "Cyberpunk and Chicago” The State of the History of Economics: Proceedings of the History of Economics Society, James P. Henderson (ed.). Taylor Francis, 49-65.

Weintraub, E. 2005. "2004 HES Presidential Address: Autobiographical Memory and the Historiography of Economics." Journal of the History of Economic Thought, 27(1), 1-11. 